\title{
DUKUNGAN INFORMASI DAN PROMOSI EKOWISATA MANGROVE BELAWAN SICANANG DALAM RANGKA PENINGKATAN PEREKONOMIAN MASYARAKAT
}

\author{
Nurmala Berutu $^{1 *}$, Meilinda Suriani Harefa ${ }^{1}$, M. Ridha Damanik ${ }^{1}$, Ahmad Hidayat ${ }^{2}$, \\ Restu ${ }^{1}$
}

\author{
${ }^{1}$ Jurusan Pendidikan Geografi, Fakultas Ilmu Sosial, Universitas Negeri Medan, Medan, Indonesia \\ ${ }^{2}$ Jurusan Akuntansi, Fakultas Ekonomi, Universitas Negeri Medan, Medan, Indonesia \\ *Penulis Korespondensi: nurmala_geo@yahoo.co.id
}

\begin{abstract}
Abstrak
Pengabdian kepada masyarakat ini bertujuan mendampingi Kelompok Sadar Wisata yang berada di Belawan Sicanang untuk mendukung penyebaran informasi dan promosi keberadaan Ekowisata Mangrove Belawan Sicanang sebagai upaya peningkatan perekonomian masyarakat setempat. Metode pendampingan yang dilakukan dengan memberikan bantuan secara langsung papan informasi memperkenalkan keberadaan Ekowisata Mangrove, memasang panduan arah menuju kawasan Ekowisata Mangrove, memasangkan atribut edukasi pada kawasan ekowisata dan pelaksanaan pelatihan yaitu: pelatihan manajemen ekowisata, pelatihan pembuatan media sosial sebagai media promosi ekowisata berbasis Teknologi Informasi (TI) kepada kelompok penggiat ekowisata di Belawan Sicanang. Dari hasil penilaian terhadap motivasi mitra dalam mengembangkan Ekowisata Mangrove sebelum dan setelah kegiatan dilaksanakan mengalami peningkatan sebesar $15,6 \%$, (sebelumnya sebesar 50\%). Respon pengunjung terhadap pemasangan media promosi dan publikasi melalui media sosial lebih dari 60\%. Dari data pengunjung yang diperoleh sejak diberikannya papan informasi dan penunjuk arah keberadaan Ekowisata Mangrove terjadi perubahan jumlah pengunjung yang datang dan beberapa lembaga bekerjasama untuk melakukan edukasi. Selama 4 Bulan melakukan kegiatan pengabdian kepada masyarakat di peroleh jumlah pengunjung mengalami pertambahan sebesar $10 \%-$ $20 \%$ dan mempengaruhi pertambahan pendapatan dari aktifitas wisata sebesar 10\%-20\% dari pendapatan sebelumnya. Selanjutnya $82 \%$ anggota kelompok menyatakan bahwa pendampingan yang berkelanjutan akan memberikan peluang untuk membangun perekonomian masyarakat disekitar kawasan Ekowisata Mangrove Belawan Sicanang.
\end{abstract}

Kata kunci: Ekowisata Mangrove Belawan Sicanang, informasi, promosi ekowsiata

\begin{abstract}
This community service aims to assist the Tourism Awareness Group in Belawan Sicanang to support the dissemination of information and promotion of the existence of the Belawan Sicanang Mangrove Ecotourism as an effort to improve the economy of the local community. The mentoring method that was carried out by providing direct assistance to the information board introduced the existence of Mangrove Ecotourism, installed direction guides to the Mangrove Ecotourism area, paired the attributes of education in the ecotourism area and carried out training namely ecotourism management training, training on making social media as information technology-based ecotourism promotion media (TI) to ecotourism groups in Belawan Sicanang. From the results of the assessment of partner motivation in developing Mangrove Ecotourism before and after the activities carried out an increase of $15.6 \%$ (previously 50\%). The visitor's response to the installation of promotional media and publications through social media is more than 60\%. From the visitor data obtained since the information board was given and a guide to the existence of Mangrove Ecotourism there was a change in the number of visitors who came and several institutions collaborated to educate. During the 4 months of community service activities, the number of visitors experienced an increase of $10 \%-20 \%$ and affected the increase in income from tourism activities by $10 \%-20 \%$ of the previous income. Furthermore, $82 \%$ of group members stated that ongoing assistance would provide an opportunity to develop the economy of the community around the Belawan Sicanang Mangrove Ecotourism area.
\end{abstract}

Keywords: Belawan Sicanang Mangrove Ecotourism, information, eco-tourism promotion 


\section{PENDAHULUAN}

Kelurahan Belawan Sicanang merupakan satu-satunya kelurahan di wilayah administrasi Kota Medan yang masih memiliki ekosistem mangrove yang cukup luas, yaitu $\pm 895,24$ ha. Namun, dalam beberapa tahun terakhir telah terjadi penurunan kualitas maupun kuantitas ekosistem mangrove akibat dari alih fungsi lahan menjadi industri, permukiman, tambak dan perkebunan sawit. Ekosistem mangrove ini memiliki fungsi yang sangat penting sebagai buffer zone Kota Medan dari bahaya banjir rob, abrasi, hempasan ombak dan tsunami. Selain itu, ekosistem mangrove juga berfungsi sebagai tempat berkembangbiaknya biota laut yang merupakan sumber matapencaharian nelayan kecil yang tinggal di wilayah pesisir. Selanjutnya pada tahun 2015, Yagasu dan Pokdarwis menginisiasi memanfaatkan zona pemanfaatan yang telah disepakati menjadi kawasan Ekowisata Mangrove Belawan Sicanang guna mempertahankan ekosistem mangrove yang tersisa di Kelurahan Belawan Sicanang dan sampai saat ini masih beropersional. Berbagai pelatihan pengembangan usaha kelompok disekitar kawasan ekowisata telah diberikan kepada ibu-ibu, pemuda dan kelompok pengelola oleh berbagai lembaga seperti pelatihan pengolahan kuliner makanan laut dan makanan dari buah mangrove sampai pada pengembangan ekowisata menjadi lokasi sekolah alam untuk anak-anak di Kelurahan Belawan Sicanang.

Berdasarkan hasil diskusi dengan kelompok pengelola Ekowisata Belawan Sicanang pelatihan yang telah diberikan selama ini belum maksimal diimplementasikan, oleh karena kurangnya pengunjung yang datang kelokasi Ekowisata Mangrove Belawan Sicanang. Jumlah kunjungan wisatawan kelokasi Ekowisata Mangrove Belawan Sicanang tentu saja mempengaruhi pembiayaan operasionalnya. Hal ini disebabkan kurangnya income dari usaha ekowisata yang kurang mampu mendanai pemeliharaan sarana prasarana yang tersedia di lokasi Ekowisata Mangrove Belawan Sicanang dan dikhawatirkan lambat laun usaha yang berpotensi mendukung perekonomian masyarakat di Kelurahan Belawan Sicanang akan tutup. Permasalahan jumlah wisatawan yang datang sedikit disebabkan minimnya informasi dan publikasi mengenai keberadaan Ekowisata Mangrove Belawan Sicanang untuk masyarakat umum dan belum adanya media sosial yang dibangun untuk mempromosikan lokasi Ekowisata Mangrove Belawan Sicanang yang berbasis Information Technology (IT).

\section{BAHAN DAN METODE}

\subsection{Bahan}

Bahan yang digunakan pada papan informasi keberadaan ekowisata mangrove, papan penunjuk arah, denah lokasi ekowisata, papan nama pohon untuk edukasi mangrove kepada pengunjung dan pembuatan media sosial untuk mempromosikan keberadaan dan kegiatan ekowisata mangrove yang berbasis Information Technology (IT).

\subsection{Metode}

Metode kegiatan dalam menyelesaikan permasalahan yang dihadapi kelompok masyarakat sebagai mitra pada kegiatan ini akan dilakukan secara bertahap adalah sebagai berikut :

1. Tahap Persiapan Sosialisasi Kegiatan

Dalam rangka pelaksanaan kegiatan pengabdian kepada masyarakat di Desa Regemuk, terlebih dahulu dilakukannya sosialisasi rencana pelaksanaan kegiatan dengan melibatkan kelompok sadar wisata Kelurahan Belawan Sicanang yang telah mengelola Ekowisata Mangrove.

2. Pembuatan Sarana Prasarana Informasi adalah :
a. Pembuatan papan informasi
b. Pembuatan papan penunjuk arah
c. Pembuatan denah lokasi
d. Pembuatan papan nama jenis pohon mangrove
e. Pembutan media sosial.

3. Pendampingan

Kegiatan pendampingan dilakukan sebagai sarana untuk penguatan manajemen usaha wisata dengan tujuan meningkatkan jumlah pengunung dan mengorganisir pembagian kerja anggota kelompok

4. Evaluasi Pelaksanaan Kegiatan

Evaluasi dilakukan pada kegatan pengabdian kepada masyarakat secara bertahap yaitu :

a. Tahap awal adalah mengukur tingkat keberhasilan dari motivasi anggota kelompok mengelola kawasan ekowisata

b. Tahap proses kegiatan

1) Kebermanfaatan sarana informasi dan dukungan yang dipasang kepada pengunjung

2) Dampak pembuatan sarana informasi dan dukungan yang dipasang kepada jumlah pengunjung

c. Tahap akhir adalah melihat keberhasilan dari kegiatan yang telah dilaksanakan. Menganalisa kegiatan pengabdian kepada masyarakat bagi mitra apakah mampu meningatkan perekonomian kelompok

Kegiatan ini merupakan adalah salah satu tuntutan dari tridharma perguruan tinggi, yaitu implementasi pengabdian kepada masyarakat. Pelaksana dalam kegiatan ini merupakan dosen dari Universitas Negeri Medan yang difasilitasi oleh Lembaga Pengabdian Kepada Masyarakat Universitas Negeri Medan. Sasaran yang menjadi mitra Unimed dalam kegiatan ini adalah Kelompk Sadar Wisata Mangrove di Kelurahan Belawan Sicanang Kecamatan Medan Belawan Kota Sumatera Utara (Gambar1). Kegiatan ini dilakukan pada bulan Agustus hingga November 2018

\section{HASIL DAN PEMBAHASAN}

Kelurahan Belawan Sicanang secara adaminsitasi termasuk dalam Kecamatan Medan Belawan Kota Medan, Provinsi Sumatera Utara. Kelurahan ini merupakan satu dari 6 (enam) kelurahan yang terdapat di Kecamatan Medan Belawan yaitu : (1) Kelurahan Belawan I, (2) Kelurahan Belawan II, (3) Kelurahan Belawan Bahari, (4) Kelurahan Belawan Bahagia, (5) 
Kelurahan Belawan Sicanang, dan (6) Kelurahan Bagan Deli. Letak astronomis Kelurahan Belawan Sicanang berada pada $3^{\circ} 44^{\prime} 16,0512^{\prime \prime} \mathrm{LU}-3^{\circ} 46^{\prime}$ 53,0148" LU dan 98 46' 34,1472" BT - 98 40' 38,3268" BT. Luas Kelurahan Belawan Sicanang yaitu kurang lebih 4.114,655 Ha, dengan batas-batas sebagai berikut :

a. Sebelah utara berbatasan dengan Sungai Belawan.

b. Sebelah selatan berbatasan dengan Kelurahan Terjun dan Kelurahan Rengas Pulau Kec. Medan Marelan Kota Medan.

c. Sebelah timur berbatasan dengan Kelurahan Belawan Bahagia dan Belawan I Kec. Medan Belawan Kota Medan.

d. Sebelah barat berbatasan dengan Kelurahan Hamparan Perak Kec. Hamparan Perak.

Sumber daya hutan mangrove yang tersisa dan terpeliharan dengan baik di kawasan Kelurahan Belawan Sicanang menjadi motivasi anggota Kelompok Sadar Wisata menjadikan kawasan ekowisata yang akan memberikan peluang terhadap peningkatan ekonomi masyarakat di sekitar kawasan Ekowisata Mangrove Belawan Sicanang. Dari hasil inventarisasi pemahaman masyarakat terhadap fungsi pemasangan papan informasi sebelum dilakukannya pengabdian 81,82 \% menjadi 90,91 \% setelah pengabdian dilakukan. pemahaman terhadap fungsi papan penunjuk arah sebelum dilakukannya pengabdian 86,36 \% menjadi 90,91 \% setelah pengabdian dilakukan, pemahaman terhadap fungsi pemasangan denah lokasi sebelum dilakukannya pengabdian $63,64 \%$ menjadi $86,36 \%$ setelah pengabdian dilakukan, pemahaman terhadap fungsi pemasangan papan nama jenis tumbuhan sebelum dilakukannya pengabdian $54,55 \%$ menjadi $77,27 \%$ setelah pengabdian dilakukan, pemahaman terhadap fungsi pembuatan media sosial untuk kawasan ekowisata sebelum dilakukannya pengabdian 63,64\% menjadi $81,82 \%$ setelah pengabdian dilakukan, pemahaman terhadap fungsi pembagian tugas anggota kelompok dalam pengembangan usaha ekowisata sebelum dilakukannya pengabdian 59,09\% menjadi $77,27 \%$ setelah pengabdian dilakukan dan pemahaman pengaruh jumlah pengunjung terhadap jumlah pendapatan masyarakat sebelum dilakukannya pengabdian $72,73 \%$ menjadi $86,36 \%$ setelah pengabdian dilakukan untuk lebih jelas dapat dilihat pada Tabel 1.

Tabel 1. Tingkat Pemahaman Mitra Sebelum dan Sesudah Kegiatan Pengabdian

\begin{tabular}{|c|c|c|c|c|c|c|}
\hline No. & Pemahaman Mitra & $\begin{array}{c}\text { Jumlah } \\
\text { Anggota } \\
\text { Kelompok }\end{array}$ & Sebelum & $\begin{array}{l}\text { Persentse } \\
(\%)\end{array}$ & Setelah & $\begin{array}{c}\text { Persentase } \\
(\%)\end{array}$ \\
\hline 1 & $\begin{array}{l}\text { Fungsi pemasangan papan } \\
\text { informasi }\end{array}$ & 22 & 18 & 81,82 & 20 & 90,91 \\
\hline 2 & fungsi papan penunjuk arah & 22 & 19 & 86,36 & 20 & 90,91 \\
\hline 3 & $\begin{array}{l}\text { Fungsi pemasangan denah } \\
\text { lokasi }\end{array}$ & 22 & 14 & 63,64 & 19 & 86,36 \\
\hline 4 & $\begin{array}{l}\text { Fungsi pemasangan papan } \\
\text { nama jenis tumbuhan }\end{array}$ & 22 & 12 & 54,55 & 17 & 77,27 \\
\hline 5 & $\begin{array}{l}\text { Fungsi pembuatan media } \\
\text { sosial untuk kawasan } \\
\text { ekowisata }\end{array}$ & 22 & 14 & 63,64 & 18 & 81,82 \\
\hline 6 & $\begin{array}{l}\text { Fungsi pembagian tugas } \\
\text { anggota kelompok dalam } \\
\text { pengembangan usaha } \\
\text { ekowisata }\end{array}$ & 22 & 13 & 59,09 & 17 & 77,27 \\
\hline 7 & $\begin{array}{l}\text { Pengaruh jumlah pengunjung } \\
\text { terhadap jumlah pendapatan } \\
\text { masyarakat }\end{array}$ & 22 & 16 & 72,73 & 19 & 86,36 \\
\hline
\end{tabular}

Dari data pada Tabel 1 menunjukkan bahwa rata-rata keseluruhan pemahaman kelompok mitra terhadap manfaat pelaksanaan pengabdian kepada masyarakat untuk dukungan informasi dan promosi Ekowisata Mangrove Belawan Sicanang sebesar 15,6\%. Hal ini menunjukkan bahwa pendampingan kepada kelompok dalam pengembangan ekowisata mampu berkontribusi terhadap peluang kemajuan ekowisata sehingga usaha ekowisata berbasis masyarakat dapat berkelanjutan (Purwiyastuti \& Wuryani, 2013). Selanjutnya dengan pemahaman yang diperoleh kelompok mitra terhadap fungsi dan manfaat informasi dan promosi terhadap pengembangan ekowisata maka diperoleh peningkatan $50 \%$ dari motivasi setelah dilakukannya kegiatan pengabdian kepada masyarakat. 


\section{Tingkat Motivasi Mitra Mengembangkan Ekowisata Sebelum dan Sesudah Pelaksanaan Pengabdian}

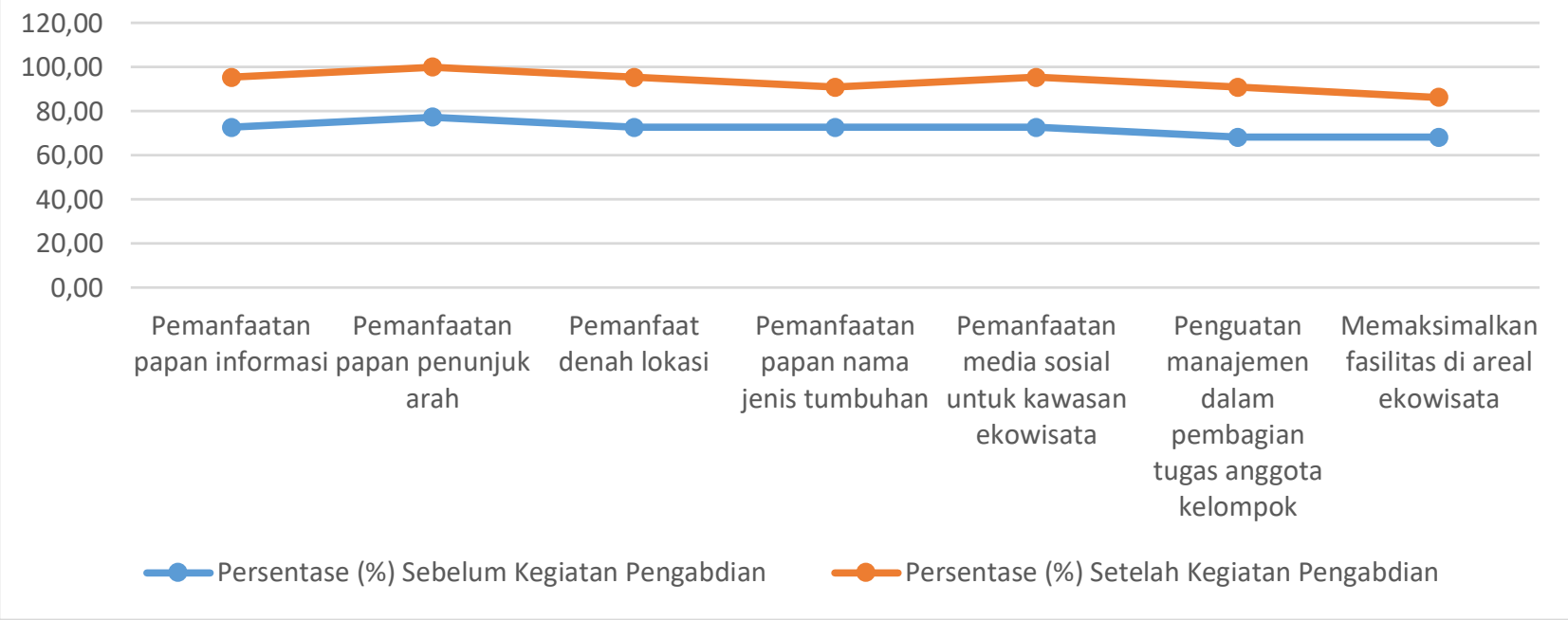

Gambar 1. Tingkat Motivasi Mitra

Data perubahan pemahaman anggota kelompok mitra sebelum dan setelah pelatihan dilakukan menunjukkan bahwa kegiatan pengabdian kepada masyarakat memiliki dampak positif terhadap pengembangan kapasitas dan keterampilan masyarakat. Hal ini sesuai dengan alasan Unimed mengembangkan program pengabdian kepada masyarakat oleh karena program ini memiliki sifat problem solving, komprehensif, bermakna, tuntas, dan berkelanjutan (sustainable) dengan sasaran yang tidak tunggal. (LPM Unimed, 2017). Berdasarkan respon pengunjung terhadap pemasangan media promosi di sekitar kawasan ekowisata mangrove dapat dilihat pada tabel 2.

Tabel 2. Respon Pegunjungan Terhadap Pemasangan Media Promosi

\begin{tabular}{|c|c|c|c|c|}
\hline \multirow{2}{*}{ No. } & \multirow{2}{*}{ Respon Pengunjung } & \multicolumn{3}{|c|}{ Persentase (\%) } \\
\hline & & Ya & Cukup & Tidak \\
\hline 1 & $\begin{array}{l}\text { Kemudahan untuk } \\
\text { menjangkau areal } \\
\text { ekowisata dari } \\
\text { keberadaan papan } \\
\text { informasi }\end{array}$ & 93,3 & 6,7 & 0,0 \\
\hline 2 & $\begin{array}{l}\text { Papan informasi } \\
\text { terpasang dan dapat } \\
\text { dilihat dengan jelas }\end{array}$ & 73,3 & 6,7 & 20,0 \\
\hline 3 & $\begin{array}{l}\text { Kebermanfaatannya } \\
\text { penunjuk arah }\end{array}$ & 66,7 & 20,0 & 13,3 \\
\hline 4 & $\begin{array}{l}\text { Denah lokasi dapat } \\
\text { membantu tujuan } \\
\text { kunjungan }\end{array}$ & 70,0 & 20,0 & 10,0 \\
\hline 5 & $\begin{array}{l}\text { Penamaan pohon } \\
\text { dapat menjadi edukasi } \\
\text { bagi pengunjung }\end{array}$ & 63,3 & 20,0 & 16,7 \\
\hline 6 & $\begin{array}{l}\text { Publikasi media sosial } \\
\text { ekowisata } \\
\text { memberikan motivasi } \\
\text { untuk berkunjung }\end{array}$ & 60,0 & 26,7 & 13,3 \\
\hline 7 & $\begin{array}{l}\text { Ketertarikan } \\
\text { berkunjung kelokasi } \\
\text { ekowisata disebabkan } \\
\text { kemudahan akses }\end{array}$ & 73,3 & 20,0 & 6,7 \\
\hline
\end{tabular}

Tabel 2 menunjukkan bahwa persentase respon pengunjung terhadap pemasangan media promosi lebih dari $60 \%$ yang artinya bahwa manfaat media promosi yang dipasang disekitar kawasan ekowisata mangrove memberi dampak positif kepada pengunjung. Hal ini juga berpeluang untuk pengunjung dapat memberi informasi mengenai keberadaan lokasi Ekowisata Mangrove Belawan Sicanang setelah kunjungan dilakukan.(Yusnikusumah \& Sulistyawati, 2016).

Melalui data dari keuangan kelompok, diperoleh peningkatan pengunjung yang datang kelokasi ekowisata dengan data jumlah pengunjung dapat dilihat pada tabel 3 .

Tabel 3. Jumlah Pengunjung Lokasi Ekowisata

\begin{tabular}{|c|l|c|c|c|c|}
\hline \multirow{2}{*}{ No. } & \multirow{2}{*}{ Bulan } & \multicolumn{4}{|c|}{ Minggu } \\
\cline { 3 - 6 } & & I & II & III & IV \\
\hline 1 & Juli & 135 & 139 & 130 & 110 \\
\hline 2 & Agustus & 132 & 148 & 135 & 117 \\
\hline 3 & September & 145 & 164 & 149 & 128 \\
\hline 4 & Oktober & 169 & 193 & 184 & 146 \\
\hline
\end{tabular}

Jumlah pengunjung pada tabel 3 tersaji data bahwa kenaikan jumlah pengunjung sebesar $10-20 \%$ setiap bulannya berpengaruh terhadap kenaikan pendapatan dari usaha ekowisata dari hasil dana kontribusi biaya masuk walaupun saat ini belum disahkan oleh Pemerintah. Biaya kontribusi sebagai pemasukan untuk mengelola kawasan ekowisata dan kenaikan jumlah pengunjung mempengaruhi pendapatan dari daya beli 
pengunjung terhadap konsumsi yang dijual dalam kawasan Ekowisata Mangrove Belawan Sicanang. Strategi pengelolaan ekowisata yang efektif berdampak terhadap bagi kesejahteraan masyarakat (Handini, 2015).

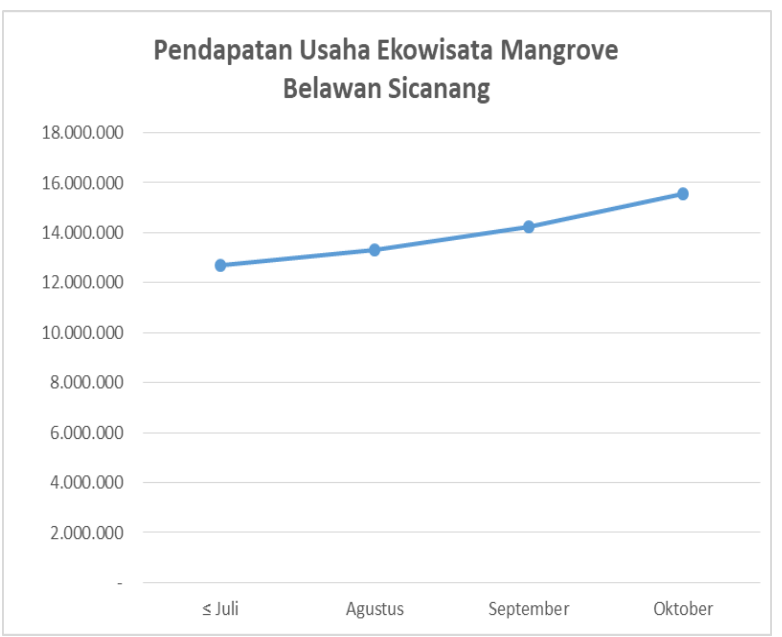

Gambar 2. Grafik Pendapat Usaha Ekowisata Mangrove

Peningkatan pendapatan ini juga menggambarkan bahwa pengelolaan ekowisata berbasis masyarakat berpeluang positif untuk memberi perubahan bagi masyarakat terutama dalam aspek ekologi dan sosial (Hijriati \& Mardiana, 2015). Dengan adanya peningkatan pendapatan, upaya untuk memepertahankan ekososistem mangrove akan maksimal (WWF-Indonesia, 2009).

Dari hasil kegiatan pengabdian kepada masyarakat pada kelompok mitra diperoleh data yang menyatakan bahwa kegiatan pendampingan berkelanjutan akan memberikan peluang terhadap untuk membangun perekonomian masyarakat disekitar kawasan Ekowisata Mangrove Belawan Sicanang sebesar $82 \%$ yang menyatakan yakin.

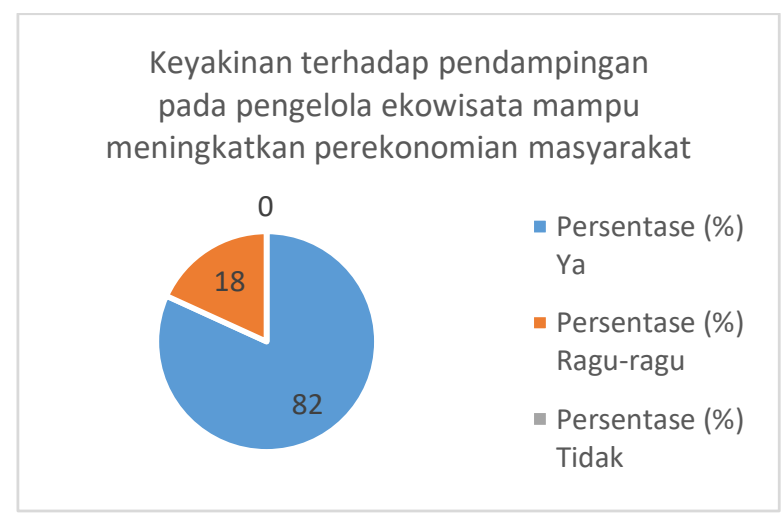

Gambar 3. Grafik Keyakinan Terhadap Pendampingan Ekowisata

Keyakinan kelompok mitra terhadap pendampingan ekowisata dapat meningkatkan perekonomian masyarakat menggambarkan bahwa kelompok mitra memiliki harapan terhadap pengembangan ekowisata mangrove yang berkelanjutan, karena dalam mengembangkan ekowisata harus ada kerjasama yang kuat antar anggota kelompok dan kerjasama dengan berbagai mitra (Damayanti, 2014)

\section{KESIMPULAN DAN SARAN}

Berdasarkan hasil dari pelaksanaan kegiatan pengabdian kepada masyarakat untuk menyebarkan informasi dan promosi keberadaan Ekowisata Mangrove Belawan Sicanang sebagai upaya peningkatan perekonomian masyarakat di Belawan Sicanang dapat disimpulkan melalui sosialisasi pelaksanaan kegiatan pengabdian masyarakat kepada kelompok mitra mampu meningkatkan pemahaman kelompok mitra terhadap kegiatan pengabdian masyarakat sebelum dan setelah kegiatan sbsebesar 15,6\% dan mempengaruhi motivasi anggota kelompok dalam mengembangkan Ekowisata Mangrove Belawan Sicanang setelah dilakukannya pendampingan sebesar $50 \%$ dari sebelumnya. Selanjutnya melalui kegiatan pengabdian kepada masyarakat mampu memberikan nilai positif terhadap pengingkatan jumlah pengunjung wisata sebesar $10-20 \%$ selama 4 bulan pelaksanaan kegiatan dan berdampak terhadap peningkatan ekonomi masyarakat dan mempengaruhi pertambahan pendapatan dari aktifitas wisata sebesar 10\% - $20 \%$ Diharapkan setelah dilakukannya pengabdian kepada masyarakat ini, mampu meningkatkan jumlah pengunjung wisata pada Ekowisata Mangrove Kelurahan Belawan Sicanang guna mempertahankan ekosistem mangrove di Kelurahan Belawan Sicanang.

\section{UCAPAN TERIMA KASIH}

Ucapan terima kasih disampaikan kepada Universitas Negeri Medan khususnya Lembaga Pengabdian Kepada Masyarakat (LPM) Unimed yang telah memberikan alokasi dana untuk pelaksanaan kegitan ini. Terimakasih juga diucapkan kepada Lurah Belawan Sicanang yang memfasilitasi tim pengabdian kepada masyarakat dengan kelompok mitra. Ucapan terima kasih juga disampaikan kepada kelompok Sadar Wisata Belawan Sicanang yang terlibat aktif dalam pelaksanaan kegiatan ini. Selanjutnya ucapan terima kasih juga disampaikan kepada seluruh tim pengabdian kepada masyarakat yang sudah berkontribusi pikiran dan waktu untuk mensukseskan kegiatan ini.

\section{DAFTAR PUSTAKA}

Drumm, Andy and Alan Moore. 2002. Ecotourism Development. An Introduction to Ecotourism Planning. The Nature Conservancy. Arlington, Virginia, USA.

Damayanti, E. dkk. (2014). Strategi Capacity Building Pemerintah Desa Dalam Pengembangan Potensi Kampoeng Ekowisata Berbasis Masyarakat Lokal (Studi di Kampoeng Ekowisata, Desa Bendosari, Kecamatan Pujon, Kabupaten Malang). Jurnal Administrasi Publik (JAP). https://doi.org/10.1017/CBO9781107415324.0 04 
Fardiah Dedeh. 2005. Focus Group Discussion. Dalam Paradigma Pembangunan Partisipatif. Jurnal Mediator Vol. 6. No. 1.

Lubis, Sutan H. 2006. Perencanaan Pengembangan Ekowisata Berbasis Komunitas Di Kawasan Wisata Tangkahan Kabupaten Langkat. Tesis. Sekolah Pascasarjana USU.

Handini, W. dkk. (2015). Strategi Peningkatan Efektivitas Pengelolaan Kawasan Konservasi Dalam Pengembangan Ekowisata Di Taman Wisata Alam Kawah Ijen. Risalah Kebijakan Pertanian dan Lingkungan: Rumusan Kajian Strategis Bidang Pertanian Dan Lingkungan. https://doi.org/10.20957/jkebijakan.v2i3.12574

Hijriati, E., \& Mardiana, R. (2015). Pengaruh Ekowisata Berbasis Masyarakat Terhadap Peruabahan Kondisi Ekologi, Sosial dan Ekonomi di Kampung Batusuhunan, Sukabumi. Sodality: Jurnal Sosiologi Pedesaan. https://doi.org/10.22500/sodality.v2i3.9422

Purwiyastuti, W., \& Wuryani, E. (2013). Model Pengembangan EKowisata Berbasis Potensi Komunitas Pedusunan. Mozaik: Jrnal Ilmu Humaniora.

Salim, Hadiwijaya dan Purbani, Dini. 2015. Pengembangan Pariwisata Bahari Berbasis Masyarakat di Pulau Kaledupa Kabupaten Wakatobi Propinsi Sulawesi Tenggara. Jurnal Manusia dan Lingkungan. Vol. 22. No. 3. 380387

Satria, Dias. 2009. Strategi Pengembangan Ekowisata Berbasis Ekonomi Lokal Dalam Rangka Program Pengntasan Kemiskinan di Wilayah Kabupaten Malang. Journal of Indonesian Applied Economics. Vol. 3 No. 1. 37-39.

WWF-Indonesia, D. K. dan P. dan. (2009). Prinsip dan Kriteria Ekowisata Berbasis Masyarakat. Ekowisata. https://doi.org/10.1177/000486580103400304

Yusnikusumah, T. R., \& Sulistyawati, E. (2016). Evaluasi Pengelolaan Ekowisata di Kawasan Ekowisata Tangkahan Taman Nasional Gunung Leuser Sumatera Utara. Jurnal Perencanaan Wilayah Dan Kota. https://doi.org/10.5614/jrcp.2016.27.3.1 